\title{
ANALISIS PENGELOLAAN UANG SAKU PADA ANAK DI SMP NEGERI 03 BP PELIUNG KABUPATEN OKU TIMUR
}

\author{
Oleh: Miftakhur Rohmah ${ }^{1}$, Rafika Ramadani ${ }^{2,}$ Puput Julia Rosmana $^{3}$ \\ rohmah@stkipnurulhuda.ac.id ${ }^{1}$, rafika@ stkipnurulhuda.ac.id ${ }^{2}$, \\ puputjuliar@gmail.com ${ }^{3}$ \\ (Program Studi Pendidikan Ekonomi, STKIP Nurul Huda Sukaraja)
}

\begin{abstract}
Abstrak-Penelitian ini bertujuan untuk mengetahui bagaimana siswa SMP N 03 dalam mengelola uang saku. Penelitian ini merupakan penelitian kualitatif dengan pendekatan deskriptif kualitatif. Tekhnik pengambilan sampel dengan Purpose sampling pada kelas VII sebanyak 14 informan, setting penelitian di SMP N 03 BP Peliung pada Bulan Maret 2021. Dari hasil penelitian pengelolaan uang saku belum maksimal, hal ini dapat dilihat dari keseharian siswa dalam membelanjakan uang jajannya yang hanya dipergunakanmembeli jajan di sekolah. Adapun siswa yang menyisihkan uang saku dari perolehan uang jajan yang diberikan orang tua setiap harinya nantinya dipergunakan untuk kegiatan yang konsumtif di luar sekolah. Belum terdapat siswa yang mengelola uang saku untuk kegiatan yang produktif. Hal-hal yang dapat mempengaruhi siswa dalam mengelola uang saku adalah lingkungan, lingkungan keluarga merupakan kunci pokok pengajaran keuangan. Melek literasi financial perlu disosialisasikan agar pendidikan keuangan untuk anak dapat tersampaikan dan teraplikasikan dikehidupan sehari-hari.
\end{abstract}

Kata Kunci : Analisis, Pengelolaan Uang Saku, pada Anak SMP

\begin{abstract}
This study aims to determine how students of SMP N 03 in managing pocket money. This research is a qualitative research with a qualitative descriptive approach. The sampling technique used is Purpose sampling in class VII as many as 14 informants, the research setting is at SMP N 03 BP Peliung in March 2021. From the results of the research, the management of pocket money has not been maximized, this can be seen from the daily activities of students in spending their pocket money which is only used to buy snacks. in school. As for students who set aside pocket money from the earning of pocket money that parents give each day, it will later be used for consumptive activities outside of school. There are no students who manage pocket money for productive activities. Things that can influence students in managing pocket money are the environment, the family environment is the key to teaching finance. Financial literacy needs to be socialized so that financial education for children can be conveyed and applied in everyday life.
\end{abstract}

Keywords: Analysis, Management of Allowances, in Junior High School Children 


\section{PENDAHULUAN}

Pendidikan adalah setiap usaha, pengaruh, perlindungan dan bantuan yang akan diberikan kepada anak yang tertuju kepada pendewasaan anak tersebut, atau lebih tepat membantu anak agar cukup cakap melaksanakan tugas hidupnya sendiri (Riandi dan Fitriani, 2018: 1) . Pengaruh itu datangnya dari orang dewasa (atau yang diciptakan oleh orang dewasa seperti sekolah, buku, putaran hidup sehari-hari dan sebagainya) dan ditujukan kepada orang yang belum dewasa. Pendidikan juga merupakan hal yang terpenting dalam kehidupan kita, ini berarti bahwa setiap manusia berhak mendapat dan berharap untuk selalu berkembang dalam pendidikan (Hidayah, 2016: 2). Pendidikan secara umum mempunyai arti suatu proses kehidupan dalam mengembangkan diri tiap individu untuk dapat hidup dan melangsungkan kehidupan. Sehingga menjadi orang terdidik itu sangat penting.

Pendidikan pertama kali yang dapatkan dilingkungan keluarga, sekolah dan masyarakat (Rufaedah, 2020: 8). Terlebih dengan sering perkembangan zaman yang semakin globalisasi dimana setiap manusia dapat dengan mudah mendapatkan sebuah pengetahuan atau informasi dari berbagai arah yang apabila manusianya tersebut tidak bias memilahnya maka akan terjadi degradasi moral. Maka dari itu peran pendidikan juga sangat besar, selain peran dari keluarga maupun masyarakatnya dalam membentuk sebuah sifat atau karakter yang baik atau positif diantaranya yaitu toleransi, saling menghargai, jujur dan hemat.

Berbicara tentang sifat hemat tentunya ada kaitannya dengan pengolahan keuangan atau uang saku yang dikelolah oleh siswa. Karena seiring perkembangan jaman, seseorang dituntut untuk biasa melakukan pengelolaan uang dengan baik. Namun, banyak kalangan yang masih sulit untuk mengelola uang tersebut. Terutama pada kalangan remaja. Uang umumnya benda yang digunakan masyarakat umum sebagai alat tukar menukar dalam perdagangan atau dengan kata lain alat pembayaran yang sah (Affandi, 2020). Dalam kegiatan perekonomian uang merupakan hal atau komponen utama dalam pembayaran barang maupun jasa. Oleh karena itu, pengelolaan keuangan dalam hal ini sangat penting demi tercukupinya kebutuhan dengan baik.

Penerapan

pengelolaan keuangan dapat diterapkan dalam kehidupan sehari-hari (Luhsasi \& Sadjiarto, 2019: 5). Hal tersebut dilakukan guna menata hidupnya demi terpenuhinya kebutuhan sekarang maupun dimasa depan. Perilaku serta sikap remaja yang boros harus dirubah, karena perilaku boros tidak akan membuat 
tercapainya pemenuhan kebutuhan sehari-hari dengan baik. Dengan kegiatan mengelola uang saku akan melatih para siswa untuk hidup tidak boros, tetapi menjadi lebih hemat.

Dari ulasan latar belakang diatas maka tujuan peneliti untuk mengetahui bagaimana siswa dalam mengelola uang saku dan apa saja yang melatar belakangi siswa dalam mengelola uang saku.

Adapun lokasi penelitian di SMP N 03 BP Peliung Kab. OKU Timur sebagai tempat penelitian karena siswa-siswi dari berbagai golongan mulai dari status sosial ekonomi keatas, status sosial ekonomi menengah maupun status sosial ekonomi kebawah. Selain itu , pada SMP N 03 siswa-siswinya berasal dari berbagai latar belakang yang berbeda-beda baik suku, budaya dan agama yang beragam. Dari keberagaman tersebut nantinya dapat memperoleh hasil data yang akurat dan sesuai dengan harapan peneliti. Sehingga peneliti tertarik melakukan penelitian terkait masalah pengelolaan uang saku di SMP N 03 BP Peliung Kab. OKU Timur.

\section{METODE PENELITIAN}

Penelitian ini termasuk penelitian lapangan (field research), yaitu penelitian yang bertujuan melakukan studi yang mendalam mengenai suatu unit sosial sedemikian rupa, sehingga menghasilkan gambaran yang terorganisir dengan baik dan lengkap
(Creswell, 2012). Dengan pendekatan deskriptif kualitatif.

Untuk menjaring data terkait pengelolaan uang saku maka peneliti terjun langsung kelapangan yakni di SMP N 3 BP Peliung, Kab. OKU Timur. untuk mengamati secara langsung fenomena yang berhubungan dengan siswa, guru, dan kepala sekolah.

Subjek penelitian diambil berdasarkan tekhnik purposive sampling, yakni sebanyak 10 siswa yang terdiri dari 5 peserta didik lakilaki dan 5 peserta didik perempuan. Sumber data diperoleh dari data primer yang bersumber langsung dari lapangan yakni melalui observasi dan wawancara mendalam dengan responden.

Pengumpulan data dengan melakukan pengamatan dan wawancara mendalam guna mendapatkan data akurat dari informan yang diperlukan peneliti untuk melengkapi data penelitian. Yakni mengenai bagaimana pengelolaan uang saku, dan faktorfaktor yang mempengaruhi siswa dalam mengelola uang saku.

Sumber data juga dari data sekunder yang berupa literaturliteratur yang diperoleh dari jurnal, buku-buku, dan referensi-referensi lain terkait pengelolaan keuangan pada anak di SMP N 03 BP Peliung Kab. OKU Timur.

Teknik pengumpulan data yakni dengan observasi/pengamatan, wawancara/interview, dokumentasi 
(Sugiyono, 2019). Selanjutnya data yang di peroleh di analisis menggunakan pendekatan deskriftif kualitatif guna memberikan gambaran yang rinci dan sesuai fakta yang ada di lapangan mengenai pengelolaan uang saku dan faktorfaktor yang mempengaruhi siswa dalam mengelola uang saku.

\section{HASIL DAN PEMBAHASAN}

Siswa-siswi SMP N 03 BP Peliung Kab. Oku Timur berasal dari berbagai golongan status sosial ekonomi , yakni dari golongan status sosial ekonomi keatas, status sosial ekonomi menengah dan status sosial ekonomi kebawah. Selain memiliki golongan status sosial ekonomi yang berbeda siswa-siswi SMP N 03 BP Peliung Kab. Oku Timur juga memiliki latar belakang yang berbeda-beda baik suku, budaya, maupun agama. Karenanya mereka memiliki bermacam perbedaan karakter dan berbagai macam pikirannya pun tidak sama. Sehingga cara mengatur uang saku sekolah mereka pun tidak sama. Hal ini dapat dilihat dari hasil penelitian menggunakan tekhnik wawancara. Responden yang dijadikan sampel dalam penelitian ini adalah 14 siswa kelas VII SMP N 03 BP Peliung Kab. Oku Timur yang terdiri dari 5 siswa laki-laki dan 9 siswa perempuan.

Berdasarkan data yang diperoleh oleh peneliti dari informan yakni siswa SMP Negeri 03 BP
Peliung, yang pertama dari seorang siswa yang bernama TS, seorang siswa berumur 12 tahun, berjenis kelamin laki-laki yang terdaftar sebagai siswa SMP N 03 BP Peliung Kab. Oku Timur. TS merupakan siswa yang jarang diberi uang saku oleh orang tua, dengan alasan ada pada masalah ekonomi, jika dilihat dari alasan tersebut TS merupakan siswa dari golongan status sosial ekonomi menengah kebawah. Karenanya dalam diri TS belum terdapat jiwa kewirausahaan. Selain TS ada 2 informan yang selalu habis dijajakan uang saku pemberian orang tuanya yakni, LA dan MZ. Mereka merupakan siswa yang diberi uang saku setiap hari sebesar 5.000,00. Kemudian ada satu informan yang diberi uang saku sebesar 10.000,00 kemudian ia menabung 5.000,00 karena keharusan dari orang tuanya, jika tidak menabung ia akan dimarah yakni SS.

Selanjutnya ada 2 informan yang sudah rutin menabung karena kemauan dari diri mereka sendiri namun belum mengarah pada jiwa kewirausahaan Yakni RZ dan MR, RZ diberi uang saku setiap hari oleh tuanya sebesar 5.000,00 . RZ merupakan siswa yang hemat dan rajin menabung, dari uang saku tersebut RZ menyisihkan seribu rupiah setiap harinya dan uang tersebut akan ia belanjakan keperluan sekolah nantinya. Sedangkan MR diberi uang saku setiap satu minggu sekali sebesar 
25.000,00 dari uang saku tersebut MR menyisihkan 5.000,00 yang kemudian sama dengan RZ uang tersebut akan dibelanjakan untuk keperluan sekolah.

Selain dari 5 Informan tersebut ada 8 informan yang juga rutin menabung karena kemauan diri mereka sendiri, mereka adalah AU, RAP, LAN, RMD, NBA, VB, MCS dan VG. Mereka diberi uang saku setiap hari oleh orang tua mereka, dan mereka menyisihkan sedikit demi sedikit untuk membeli barang yang mereka inginkan.

\section{KESIMPULAN}

1. Siswa SMP N 03 BP Peliung dalam mengelola keuangan harian mayoritas sulit dalam mengontrol keuangan karena tidak terbiasa dalam membuat rencana pengeluaran keuangan, hal tersebut dibuktikan dari kebiasaan hidup royal dan sulit untuk saving ataupun menabung.

2. Dalam mengelola keuangan yang diberikan oleh orang tua hanya digunakan untuk kepentingan konsumtif semisal jajan, membeli kuota dan barang-barang lainya. hal tersebut didukung dengan temuan bahwa mayoritas siswa menabung hanya untuk kegiatan konsumtif ataupun takut dengan orang tua.

3. Faktor yang berpengaruh dalam menentukan pengelolaan keuangan yang baik dan benar yakni didominasi oleh faktor lingkungan. Dari beberapa Informan di peroleh gambaran bahwasanya pengelolaan keuangan yang di setting lingkungan dengan literasi financial yang matang terbukti mampu membuat minoritas siswa mengelola keuangan dengan baik, mampu mengontrol kegiatan konsumtif dengan skala prioritas, dan dapat menyisihkan uang jajan untuk kegiatan saving. Hal tersebut dapat menjadi tolak ukur bahwa lingkungan mampu mempengaruhi siswa dalam mengelola keuangan.

Adapun Saran bagi informan hendaknya membuat skala prioritas agar dapat mengontrol keuangan dan dapat hidup lebih hemat karena ekonomi pada setiap harinya belum bisa ditargetkan atau dikontrol, sehingga menghemat dapat menjadi alternatif untuk memenuhi kebutuhan sekunder ataupun tersier untuk anak. Selanjutnya untuk orang tua seyogyanya mulai mengenalkan literasi financial kepada anak sejak dini untuk pengelolaan keuangan yang baik. Sehingga kedepannya anak dapat hidup hemat dan mampu menentukan skala prioritas dalam berekonomi serta mampu menggunakan uang sakunya untuk kegiatan-kegiatan produktif. 


\section{UCAPAN TERIMA KASIH}

Penulis mengucapkan banyak terima kasih kepada semua pihak yang telah membantu dari proses awal penulisan hingga bisa terbitnya tulisan ini. Kepada STKIP Nurul Huda sebagai Institusi yang mendanai penelitian ini melalui Hibah kampus sesuai dengan kontrak 034/STKIP-NH/LPPM/II/2021.

Kepada pengelola jurnal NERACA yang telah bersedia menerbitkan tulisan ini.

\section{DAFTAR PUSTAKA}

Riadin, A., \& Fitriani, C. L. (2018). Upaya Meningkatkan Hasil Belajar Ipa Menggunakan Model Pembelajaran Kooperatif Tipe Jigsaw Dengan Berbantuan Media Alat Peraga Konkret Pada Peserta Didik Kelas V SDN-4 Kasongan Baru Tahun Pelajaran 2016/2017. Pedagogik: Jurnal Pendidikan, 13(2), 1-5.

Hidayat, Z. (2016). Pengaruh stres dan kelelahan kerja terhadap kinerja guru SMPN 2 Sukodono di kabupaten lumajang. WIGA-Jurnal

Penelitian Ilmu Ekonomi, 6(1), 36-44.

Affandi, F. (2020). Fungsi Uang Dalam Perspektif Ekonomi Islam. Eksya: Jurnal Ekonomi Syariah, 1(1), 80-91.

Luhsasi, D. I., \& Sadjiarto, A. (2019). Penerapan Mental Accounting Dalam Edukasi Pengelolaan Keuangan Tim Basket SWS. Jurnal Profesi Pendidik, 5.
Rufaedah, E. A. (2020). Peranan pendidikan agama dalam keluarga terhadap pembentukan kepribadian anak-anak. Counselia; Jurnal Bimbingan Konseling Pendidikan Islam, 1(1), 8-25.

Creswell,W.J. (2012). Planning, Conducting, and Evaluating Quantitative and Qualitative Research. Boston : Pearson.

Sugiyono. (2019). Metode Penelitian Kuantitatif dan Kualitatif dan R\&D. Bandung: CV Alfabeta 